\title{
Pengaruh Anggaran Kas sebagai Alat Perencanaan dan Pengendalian Terhadap Tingkat Likuiditas Pada Toko Kue Dapur Amien
}

\author{
Vince Ariany \\ Politeknik Ganesha Medan \\ Jl. Veteran No.194 Pasar VI Manunggal \\ vinceariany76@gmail.com
}

\author{
Sinta Sintia \\ Politeknik Ganesha Medan \\ Jl. Veteran No.194 Pasar VI Manunggal \\ sintiashinta12@gmail.com
}

\begin{abstract}
ABSTRAK
Tujuan dari penelitian ini adalah untuk mengetahui pengaruh anggaran kas, sebagai alat perencanaan dan pengendalian terhadap tingkat likuiditas pada Toko Kue Dapur Amien. Penelitian ini menggunakan metode kualitatif deskriptif. Analisa dilakukan dengan cara mengumpulkan data serta menganalisis tentang cara penggunaan anggaran kas untuk membuat perbandingan antara teori dengan praktek dan dituangkan untuk menerangkan suatu penjelasan dari angka-angka kemudian dijelaskan kembali dalam bentuk uraian bahasa prosa atau baku. Hasil penelitian ini menerima, anggaran kas sebagai alat perencanaan dan anggaran kas sebagai alat pengendalian secara bersama-sama memberikan pengaruh secara signifikan terhadap tingkat likuiditas.
\end{abstract}

Kata Kunci: Anggaran Kas, Perencanaan, Pengendalian, Likuiditas

\section{PENDAHULUAN}

Setiap perusahaan dalam menjalankan aktivitas usahanya selalu ingin berkembang yang menyebabkan semakin banyaknya masalah yang dihadapi manajemen sehubungan dengan kebutuhan modal kerja perusahaan. Alat yang dapat digunakan oleh manajemen dalam pengelolaan keuangan perusahaan adalah anggaran. Anggaran merupakan alat manajerial yang menjamin pencapaian sasaran organisasi dan memberikan pedoman dalam bentuk mata uang untuk operasional sehari-hari. Keefektifan anggaran merupakan ukuran keberhasilan organisasi dalam melakukan penghematan terhadap keuangan organisasi.

Untuk itu, maka perusahaan harus bisa menyusun anggaran kas, yang bertujuan untuk menyusun rencana dan untuk menjamin bahwa kas yang digunakan dalam anggaran kas tersebut cukup, tidak terlalu besar dan tidak terlalu kecil. Dengan adanya anggaran kas perusahaan maka akan sangat membantu perusahaan dalam melakukan perencanaan dan pengendalian kas, sehingga penerimaan dan pengeluaran kas dapat terkendali sesuai dengan perencanaan yang telah ditetapkan oleh perusahaan sebelumnya. Penulis merumuskan masalah penelitian yaitu: Bagaimana pengaruh anggaran kas sebagai alat perencanaa dan pengendalian terhadap tingkat likuiditas pada Toko Dapur Amien. 
Adapun tujuan dari penelitian yang dilakukan penulis adalah: Untuk mengetahui pengaruh anggaran kas sebagai alat perencanaan dan pengendalian terhadap tingkat likuiditas pada Toko Kue Dapur Amien yang terjadi pada tahun 2014 pada toko kue dapur amien.

Batasan masalah, Dalam penelitian ini penulis membuat batasan penelitian mengenai anggaran dan tingkat likuiditas.

\section{LANDASAN TEORI}

Anggaran (budget) merupakan rencana tertulis mengenai kegiatan suatu organisasi yang dinyatakan secara kuantitatif untuk jangka waktu tertentu dan umumnya dinyatakan dalam satuan uang, tetapi dapat juga dinyatakan dalam sautuan barang/jasa. Macam-macam Anggaran:a. Anggaran variabel, b.Anggaran tetap.

Fungsi dan Manfaat Anggaran: a. Sebagai pedoman kerja, b. Sebagai perencanaan, c. Sebagai alat pengendalian.

Keuntungan dan Kelemahan Penyusunan Anggaran:

Keuntungannya:

a. Mempercepat dan mengefensiekan pencapaian tugas.

b. Dapat menilai kemajuan kerja (progres) pencapaian tujuan.

Kelemahannya

a. Anggaran dibuat berdasarkan taksiran dan anggapan sehingga mengandung umur ketidakpastian.

b. Menyusun anggaran yang cermat memerlukan waktu, uang, dan tenaga yang tidak sedikit sehingga tidak semua perusahaan mampu menyusun anggaran secara lengkap (komperhensif) dan akurat.

\section{Anggaran Kas}

Menurut Bambang Riyanto, 1996 dalam Mustfee (2013) anggaran kas adalah estimasi terhadap posisi kas untuk periode tertentu yang akan datang. Anggaran kas adalah sarana perencanaan bulan demi bulan atau minggu demi minggu yang sangat spesifik, biasanya disusun oleh staf keuangan suatu perusahaan.

Manfaat dan Tujuan Anggaran Kas: a. Sebagai pedoman kerja, b. Sebagai alat pengkordinasi kerja, c. Sebagai alat pengawasan kerja. Adapun anggaran kas memiliki beberapa tujuan yaitu: a. Menentukan posisi kas pada berbagai waktu dengan membandingkan uang kas masuk dengan uang kas keluar. b. Memperkirakan kemungkinan terjadinya defisit atau surplus.

Penyusunan anggaran kas mencakup dua sektor yaitu : (1) sektor penerimaan kas, (2) sektor pengeluaran kas.Bentuk anggaran kas yaitu: Bentuk standar yang harus dipergunakan masing-masing perusahaan mempunyai kebebasan untuk menentukan bentuk serta formatnya.

\section{Rasio Keuangan}

Penggunaan Rasio Keuangan ini akan menunjukkan nilai kinerja perusahaan apakah sudah tergolong baik atau belum. Rasio ini juga bisa memberikan gambaran kinerja saat ini yang diproyeksikan ke masa mendatang. 


\section{III.METODOLOGI PENELITIAN}

Penelitian ini dilaksanakan pada Toko Dapur Amien di Jalan Cemara Asri Beulevard Raya N0 120. Waktu penelitian dilakukan mulai bulan januari sampai dengan selesai.

Jenis Data

a. Data primer, dimana peneliti mengumpulkan informasi mengenai sejarah singkat Toko Kue Dapur Amien, informasi dan struktur organisasi, dengan menggunakan teknik wawancara kepada pihak tertentu.

b. Data sekunder, dimana peneliti mengumpulkan data informasi Toko Kue Dapur Amien visi dam misi, logo dan makna logo yang diperoleh dari kepustakaan Toko Kue Dapur Amien.

\section{Sumber Data}

Sumber data yang digunakan dalam penelitian ini adalah sumber data internal yang diambil dari Toko Kue Dapur Amien.

\section{Metode Pengumpulan Data}

1. Studi Lapangan (Field Research), Yaitu metode penelitian dengan cara melakukan pengamatan langsung pada Toko Kue Dapur Amien, dan wawancara langsung pada pihak-pihak yang berkaitan dengan perusahaan yang dikerjakan(interview).

2. Pengamatan (Observation)

Yaitu dalam proses penelitian ini,penulis melakukan pengamatan secara langsung atau pinjaman terhadap kegiatan yang enjadi contoh dalam penelitian.

3. Wawancara (Interview)

Yaitu dalam proses penelitian ini penulis melakukan tanya jawab antara penulis dengan pemilik

Toko Kue Dapur Amien. Dalam hal wawancara tersebut, penulis mencoba memperoleh informasi yang diperlukan.

\section{Metode Analisis Data}

Metode penelitian yang digunakan dalam penelitian ini adalah kualitatif deskriptif, yaitu dengan serangkaian kegiatan yang dilakukan dengan cara mengumpulkan data toko kue dapur amien serta menganalisis tentang cara penggunaan anggaran kas. Selanjutnya membuat perbandingan antara teori dengan praktek yang berlaku dilapangan.

\section{IV.PEMBAHASAN}

\section{Proses Penyusunan Anggaran Kas}

Dalam penyusunan anggaran kas pada Toko Dapur Amien yaitu penyusunan anggaran dimana anggaran disusun dan disiapkan oleh pihak yang melaksanakan anggaran tersebut.

Tahap-tahap penyusunan anggaran kas pada Toko Dapur Amien adalah sebagai berikut: 1) Pihakpihak penyusunan anggaran kas adalah sekretaris, bendahara. 2) Pengurus Toko Dapur Amien membuat daftar perencanaan kas yang digunakan untuk kegiatan operasionalnya untuk anggaran tahun mendatang. 


\section{Faktor-Faktor Penyebab Perbedaan Atau Selisih (Varians) Antara Anggaran Dan Realisasi Anggaran Kas Pada Toko Dapur Amien}

Berikut tabel rincian anggaran dan realisasi anggaran kas padaToko Dapur Amien tahun 2015 dan 2016.

\section{Anggaran dan Realisasi anggaran kas Toko Dapur Amien}

Tahun 2015

\begin{tabular}{|c|c|c|c|c|c|}
\hline No & URAIAN & \multirow{2}{*}{ ANGGARAN } & \multirow{2}{*}{ REALISASI } & \multirow{2}{*}{ SELISIH } & \multirow{2}{*}{ KETERANGAN } \\
\hline \multicolumn{2}{|c|}{ 1. Penerimaan Kas } & & & & \\
\hline 1 & Pendapatan Usaha & Rp1.800.000.000 & Rp1.590.327.751 & \multirow{2}{*}{$\begin{array}{l}\text { Rp209.672.249 } \\
(\operatorname{Rp} 10.774 .222)\end{array}$} & Kurang baik \\
\hline \multirow[t]{2}{*}{2} & Piutang & Rp190.000.000 & Rp 200.774.222 & & Baik \\
\hline & Kas Tersedia & Rp2.000.000.000 & Rp1.781.101.973 & Rp218.898.027 & Kurang baik \\
\hline \multicolumn{6}{|c|}{ II. Pengeluaran Kas } \\
\hline 1 & $\begin{array}{l}\text { Pembelian bahan } \\
\text { baku }\end{array}$ & $\operatorname{Rp} 500.000 .000$ & Rp 589.674.892 & $(\operatorname{Rp} 89.674 .892)$ & Baik \\
\hline \multirow[t]{2}{*}{2} & $\begin{array}{l}\text { Pembayaran } \\
\text { Hutang }\end{array}$ & $\operatorname{Rp} 178.500 .000$ & Rp $\quad 97.512 .600$ & Rp80.987.400 & Kurang baik \\
\hline & Saldo Kas Akhir & Rp1.321.500.000 & Rp1.093.914.481 & Rp227.585.519 & Kurang baik \\
\hline
\end{tabular}

Sumbser:Toko kue dapur amien (2018)

Dari tabel anggaran dan realsasi anggaran kas diatas, dapat dilihat secara keseluruhan untuk tahun 2013 bahwa anggaran dari segi penerimaan kas sebesar Rp 2000.000.000 namun realisasinya sebesar $\mathrm{Rp}$ 1.781.101.973 dimana terdapat selisih tidak menguntungkan (Unfarvorable) sebesar Rp 218.898 .027 yang disebabkan turunnya penerimaan kas dari pendapatan usaha dimana anggaran yang dianggarkan sebesar $\mathrm{Rp} 1.800 .000 .000$ dan realisasinya hanya $\mathrm{Rp} 1.590 .327 .751$ sehingga terdapat selisih anggaran tidak menguntungkan sebesar Rp 209.672.249.

Hal ini disebabkan karena sebagian besar anggota melunasi hutang kredit tidak tepat waktu dan kurangnya penanganan.

Atas penagihan piutang/kredit anggota. Namun pada pendapatan usaha penerimaan kas yang dianggarkan sebesar Rp 200.000.000 yang realisasinya sebesar Rp 190.774.222 selisihnya mengalami kenaikkan sebesar $\mathrm{Rp}$ 9.225.778 atau menguntungkan yang dikarenakan meningkatnya pendapatn dari luar pendapatan usaha yang berupa pendapatan bunga dari pihak lain serta meningkatnya penerimaan pendapatan dari luar usaha. 
Sedangkan pengeluaran kas pada anggaran kas Toko Dapur Amien sebesar Rp 1.321.500.000 sedangkan realisasi anggaran kas sebesar Rp1.093.914.481 sehingga terdapat selisih menguntungkan (farvorable) Rp227.585.519 yang disebabkan karena realisasinya lebih kecil dari yang dianggarkan.

\section{Anggaran dan Realisasi anggaran kas Toko Dapur Amien}

Tahun 2016

\begin{tabular}{|c|c|c|c|c|c|}
\hline No & URAIAN & ANGGARAN & REALISASI & SELISIH & KETERANGAN \\
\hline \multicolumn{6}{|c|}{ I. Penerimaan Kas } \\
\hline 1 & Pendapatan Usaha & $\operatorname{Rp} 2.000 .000 .000$ & Rp1.742.896.925 & Rp257.103.075 & Kurang Baik \\
\hline \multirow[t]{2}{*}{2} & Piutang Usaha & $\operatorname{Rp} \quad 196.000 .000$ & $\mathrm{Rp} 218.405 .000$ & $\operatorname{Rp}(22.405 .000)$ & Baik \\
\hline & Kas Tersedia & Rp2.196.000.000 & Rp1.961.301.925 & Rp234.698.075 & Kurang Baik \\
\hline \multicolumn{6}{|c|}{ II. Pengeluaran Kas } \\
\hline 1 & $\begin{array}{l}\text { Pembelian bahan } \\
\text { baku }\end{array}$ & $\operatorname{Rp} \quad 597.500 .000$ & Rp 601.373.158 & $\operatorname{Rp}(3.873 .158)$ & Baik \\
\hline \multirow[t]{2}{*}{2} & Pembayaran Hutang & $\operatorname{Rp} 200.000 .000$ & Rp 154.213.125 & $\operatorname{Rp} 45.786 .875$ & Kurang Baik \\
\hline & Saldo Kas Akhir & Rp1.398.500.000 & Rp1.205.713.642 & Rp192.786.358 & Kurang Baik \\
\hline
\end{tabular}

Sumbser:Toko Dapur Amien (2018)

Dari tabel anggaran dan realisasi anggaran kas diatas, dapat dilihat pada tahun 2015 anggaran dari segi penerimaan kas sebesar Rp2.196.000.000 namun realisasinya sebesar Rp1.961.301.925 dimana terdapat selisih tidak menguntungkan (unfarvorable) sebesar Rp234.698.075 yang disebabkan turunnya penerimaan kas baik dari pendapatan usaha maupun piutang usaha dimana pendapatan usaha berasal dari penerimaan piutang anggota yang sebagian besar anggota melunasi utang kredit tidak tepat waktu karena kurangnya penanganan atas piutang kredit macet anggota.

Sedangkan dari pengeluaran kas pada anggaran kas Toko Dapur Amien Rp1.398.500.000 sedangkan realisasi anggaran kas sebesar Rp1.205.713.642 dimana terdapat selisih menguntungkan (farvorable) sebesar Rp192.786.358 yang dikarenakan dari segi pembayaran hutang bunga, biaya manajemen dan kegiatan administrasi dan umum realisasinya lebih kecil dari yang dianggarkan.

Dari hasil evaluasi data anggaran dan realisasi anggaran kas pada tahun 2015 dan 2016 berupa penerimaan dan pengeluaran kas secara keseluruhan sudah dapat dikendalikan secara baik pertransaksinya, meskipun ada perbedaan dan penyimpangan. Tetapi perbedaan anggaran dan realisasi anggaran kas yang terjadi masih wajar karena dapat diantisipasi oleh 
kepengurusan yang bersangkutan. Faktor utama yang dipertimbangkan dalam penyusunan anggaran pada Toko Kue Dapur Amien adalah realisasi tahun yang lalu atau tahun sebelumnya.

Sedangkan dari pengeluaran kas pada anggaran kas Toko Dapur Amien Rp1.398.500.000 sedangkan realisasi anggaran kas sebesar Rp1.205.713.642 dimana terdapat selisih menguntungkan (farvorable) sebesar Rp192.786.358 yang dikarenakan dari segi pembayaran hutang bunga, biaya manajemen dan kegiatan administrasi dan umum realisasinya lebih kecil dari yang dianggarkan. 
Dari hasil evaluasi data anggaran dan realisasi anggaran kas pada tahun 2015 dan 2016 berupa penerimaan dan pengeluaran kas secara keseluruhan sudah dapat dikendalikan secara baik pertransaksinya, meskipun ada perbedaan dan penyimpangan. Tetapi perbedaan anggaran dan realisasi anggaran kas yang terjadi masih wajar karena dapat diantisipasi oleh kepengurusan yang bersangkutan. Faktor utama yang dipertimbangkan dalam penyusunan anggaran pada Toko Kue Dapur Amien adalah realisasi tahun yang lalu atau tahun sebelumnya.

Anggaran kas sebagai alat perencanaan dan pengendalian Ada dua keuntungan yang umum terjadi pada biaya yaitu penyimpangan yang menguntungkan (Favorable Varience) dan penyimpangan yang tidak menguntungkan (Unfavorable Varience). Terlihat pada tahun 2015 anggaran berada dibawah realisasi dan terjadi penyimpangan yang merugikan (Unfavorable Varience).

\section{Anggaran Kas Sebagai Alat Perencanaan}

Perencanaan anggaran kas pada Toko Dapur Amien kurang baik dilihat dari pertimbanganpertimbangan yang dilakukan oleh Toko Dapur Amien kegiatan rutin dan kegiatan yang tidak rutin. Namun sebaiknya dalam proses perencanaan harus dilakukan analisis dalam perencanaan anggaran kas sebaiknya dilakukan secara seksama, sehingga setiap kegiatan dapat berjalan dengan baik dan perubahan yang terjadi dapat ditangani dengan cepat dan tepat oleh Toko Dapur Amien.

\section{Anggaran Kas Sebagai Alat Pengendalian}

Pengendalian terhadap anggaran kas yang dilakukan oleh toko dapur amien telah berjalan dengan tidak baik hal ini dapat dilihat dari mengontrol seluruh kegiatan yang dilakukan agar apa yg telah ditarget kan terrcapai. Meliputi, pengendalian atass suatu penyimpangan anggaran kas, baik anggaran itu menguntungkan (farforable) atau pun tidak mmenguntukan (unfarforable).

Toko Dapur Amien sebaiknya melakukan pengendalian di awal bulan anggaran jika anggaran dibulan sebelumnya mengalami kekurangan, maka toko dapur amien meminta dana tersebut dibulan berikutnya.

\section{KESIMPULAN}

Peneliti dapat menarik beberapa kesimpulan dari analisis anggaran kas sebagai alat perencanaa dan pengendalian sebagai berikut:

1) Anggaran kas sebagai alat perencanaan pada Toko Kue Dapur Amien belum baik, karena pada saat perencanaan anggaran pihak yang bersangkutan belum membuat tim anggaran yang terdiri sekretaris bendaharan dan bagian unit lainnya.

2) Dilingkungan kepengurusan Toko Kue Dapur Amien. Dimana dalam melakukan suatu anggaran tidak banyak mebuat pertimbangan dalam penyusunan anggarannya.

3) Anggaran kas sebagai alat pengendalian pada Toko Kue Dapur Amien belum berjalan dengan baik yang dapat dilihat dari upaya mengontrol seluruh kegiatan yang dilakukan oleh yang bersangkutan tidak akurat dalam target yang ingin dicapai,selain itu untuk 
menemukan penyimpangan-penyimpangan yang mungkin terjadi agar dapat segera dilakukan tindakan antisipasi dan revisi.

Berdasarkan hasil dari penelitian yang dilakukan maka saran yang dapat dijadikan bahan pertimbangan adalah sebagai berikut:

1. Sebaiknya Toko Kue Dapur Amien Medan melakukan (koreksi) setiap 6 bulan sekali untuk mengetahui penyimpangan anggaran yang terjadi, sehingga terjadinya penyimpangan-penyimpangan anggaran dapat diketahui dengan cepat dan untuk menghindari terjadinya pemborosan atau hal yang tidak menguntungkan bagi Toko Kue Dapur Amien.

2. Sebaiknya Toko Dapur Amien membuat laporan anggaran kas yang lebih terperinci lagi, mengenai pos-pos akun anggaran kas sehingga dapat diketahui dengan cepat apabila ada penyimpangan yang terjadi.

\section{REFERENSI}

Pane Abdi Ananda, Reza (2017). Pengaruh Anggaran Biaya Sebagai Alat Perencanaan dan Pengendalian Terhadap Tingkat Likuiditas Pada . Tugas Akhir. Politeknik Ganesha Medan: Medan

Irwadi, Maulana. (2015). Analisis anggaran Kas Sebagai Alat Pengendalian Dan

Perencanaan Pada Koperasi Kopdit Rukun Palembang. Jurnal Akuntansi.

Depdiknas. (2009). Pengertian Anggaran Menurut Para Ahli.

http://infodanpengertian.blogspot.co.id/2016/01/pengertian-anggaran-menurut-paraahli.html.

Maulidya, Nungky. (2013). Macam-macam Anggaran.

https://nungkymaulidyaew.blogspot.co.id/2018/03/macam-macam anggaran-anggarandapat.html. Diakses 30 Maret 2018

M. Nafarin. (2004) Penggaran Perusahaan, Jakarta: Salemba Empat.

Ibrahim, Adzikra. (Tanpa Tahun). Pengertian Likuiditas, Fungsi Likuiditas, Dan Komponen Didalamnya. https://pengertiandefinisi.com/pengertian-

likuiditas-fungsi-likuiditas-dan-komponen-di-didalamnya/

Surya Kurnia, Sonny. (2018). Bab III Landasan Teori Dan Tinjauan Praktik Prosedur Penyusunan Anggaran Kas Dan Perencanaan Arus Kas Pada Badan Lingkungan Hidup Provinsi Jawa Tengah. http://docplayer.info/74413151-Bab-iii-landasan-teori-dan-tinjauan-praktik-prosedurpenyusunan-anggaran-kas-dan-perencanaan-arus-kas-pada-badan-lingkungan-hidupprovinsi-jawa-tengah.html.

Supiandi. (2012). Pengaruh Anggaran Kas Terhadap Tingkat Likuiditas Pada PT. PLN (Persero) Jawa Barat. Skripsi. Falkutas Ekonomi Universitas Pasundan: Bandung

Purwatiningsih dan Maudy Warou. (2003). Anggaran Perencanaan dan Pengendalian Laba. Jakarta: Salemba Empat 
Profil Toko Dapur Amien. 